\title{
The Impact of Cash Flow Statement on Lending Decision of Commercial Banks: Evidence from Vietnam*
}

\author{
Dung Duc NGUYEN ${ }^{1}$, Anh Huu NGUYEN ${ }^{2}$
}

Received: March 04, 2020 Revised: April 11, 2020 Accepted: May 01, 2020

\begin{abstract}
The paper investigates the impact of the statement of cash flows of listed companies on lending decisions of commercial banks in the context of Vietnam. Survey data for the research were collected from 160 credit officers of Vietnamese commercial banks for short-term and long-term lending decisions, whether the cash flow statement includes complete information or has a lack of information. The cash flow statement, in which the information on the cash flow is completely contrary to the profit information on the income statement is examined. This paper employed T-tests to address the research issues in a market considered to be ineffective, like Vietnam. The research results show: (1) the information on the cash flow statement affects both the short-term and long-term lending decisions of credit officers, and (2) the lack of information on the cash flow statement in both cases of positive and negative profits affects the comfort and confidence of credit officers in making decisions. The research findings also indicate that cash flow statements are important for lending decisions of credit institutions in Vietnam. Therefore, this paper provides a new insight to managers on how to improve the quality of cash flow statement to meet the needs of lenders.
\end{abstract}

Keywords : Cash Flow Statement, Decision Making, Lenders, Vietnam Stock Market, Non-Financial Listed Companies.

JEL Classification Code: G30, M40, M41, D81, G11

\section{Introduction}

The system of financial statements is a key tool that provides important information on which users base their decisions to directly benefit investors, lenders and assist managers to run business activities. According to some studies, people use financial statements while assessing a firm primarily through the balance sheets and the income statements, with little interest in cash flow statements.

'This research is funded by the National Economics University (NEU), Hanoi, Vietnam. The authors thank anonymous referees for their contributions and the NEU for funding this research.

${ }^{1}$ First Author and Corresponding Author. Lecturer, School of Accounting and Auditing, National Economics University, Vietnam [Postal Address: 207 Giai Phong Road, Dong Tam Ward, Hai Ba Trung District, Hanoi, 116000, Vietnam]

Email: dungnd2141@gmail.com

${ }^{2}$ Dean, School of Accounting and Auditing, National Economics University, Vietnam. Email: anhnh@neu.edu.vn

(c) Copyright: The Author(s)

This is an Open Access article distributed under the terms of the Creative Commons Attribution Non-Commercial License (http://Creativecommons.org/licenses/by-nc/4.0/) which permits unrestricted noncommercial use, distribution, and reproduction in any medium, provided the original work is properly cited.
However, the general belief in the above two types of financial statements was greatly shaken when WT Group Grant Company went bankruptcy while its profits from business operations were good, its annual profits amounting to more than $\$ 40$ million. Largay and Stickney (1980) pointed out the revenues generated by the company from business activities were not enough to compensate for the amount of money that it must spend, resulting in a negative cash flow over five consecutive years. The WT Group Grant Company is still being used today as an example of how cash flow analysis can be used in detecting financial distress or as a way to differentiate a firm's cash flows from its reported net income

Lenders are always considered among those who use financial statements of firms. Erich (2001) determined that those who use financial statements for lending decisions should consider cash flow statements to assess the financial condition of a firm. Along with the development of the economy, Vietnam stock market was established and continues developing. In the context of strong international integration, to promote their role and strengths in the national economy, listed companies should complete the financial reporting system, in which cash flow statement 
is a component. The cash flow statement has been globally studied in the last few decades, including a focus on the influence of accounting information on the statement of cash flows to lenders of firms. However, the issue has not been significantly studied in developing countries, especially Vietnam. For the lenders, sufficient and useful accounting information on the cash flow statement provided may help them to fully and comprehensively analyze and evaluate the business performance, thus to ensure the lenders make reasonable loan decisions in order to avoid risks and improve the efficiency of capital lending.

\section{Literature Review}

In the process of developing cash flow statements, researchers focus on providing information to each user, especially the lenders. One of those who are most interested in cash flow statements is a lender. The cash flow statement is of special importance to the solvency of firms, which is useful information for lenders. In addition, cash flow statements assess the ability of firms to pay dividends and debt obligations, giving lenders more information to make decisions (Kwork, 2002). The cash flow statement is specially important to the view on the solvency of the enterprise. In addition, the cash flow statement assesses the ability of enterprises to pay dividends and meet obligations in debt. Nguyen and Duong (2019); Nguyen, Pham and Nguyen (2020) analyzed the adjustment of profits taking place in a systematic manner, showing that many factors affect the profit adjustment. For creditors, the solvency of the business, especially in the short term, is an important factor for the creditor's lending decision.

From the lenders' perspective, the solvency of the business, especially in the short term, is an important factor for their lending decision. The borrower needs to answer three questions: can the borrower repay the loan, how does the borrower use the loan during its operation, and how does the borrower manage the loan. Lenders should take a look at the cash flow statement of the business to analyze and answer these three questions. Making a cash flow statement today is not simply making it available. The cash flow statement provides information as important as the financial condition of a business by providing a cash flow plan for the current year and reviewing the effects that determine the current cash flow strategy in the next phase (Turpin, Smith $\&$ Fulmer, 2005). For Nguyen and Vu (2014), the cash flow statement provides information as important as the financial health of a business in that it provides a cash flow plan for the year and considers the effects that determine the cash flow strategy. Therefore, any conclusions drawn from the cash flow statement must be combined with an in-depth understanding of the business.
In addition, the information on cash flow statements is particularly important to recognize the business failure. Most of the studies have concentrated their analysis on operating cash flows. This emphasis may be a response to criticisms of the accrual process used by the accounting profession in assessing firms' financial performance and future cash flows (Neill, Schaefer, Bahnson \& Bradbury, 1991). Previous studies report consistent evidence on the predictive ability of operating cash flows. Operating cash flows help discriminate financially distressed firms and healthy firms relative to other financial information. Operating cash flow has a greater ability to determine financial distress than other financial information.

Zordan (1998) provided assumptions on cash flow indicators related to predicting business failures in retail, wholesale and manufacturing businesses. The author conducted a study of 270 US bankrupt firms and nearly 300 successful firms between 1990 and 1997. The firms were listed companies on the US stock exchange. He also compared the accuracy of the predictability of business success or failure in two models related to cash flow and accrual basis. The study reveals that the cash flow indicator predicted business failures of retail, wholesale and manufacturing businesses with an accuracy rate of nearly $80 \%$. The study confirms that the information on the cash flow statement is important for information users. However, the study does not indicate the difference in business prediction between the failure prediction model through cash flow and that through analysis criteria on accrual accounting basis.

Catanach (2000) showed that all bankrupt firms have problems in the cash flow information, which is reflected in the cash flow indexes calculated through the cash flow statements. Firms can survive with continuously declining corporate profits, but cannot extend their life if there is no money left. Another study provides a model to predict the bankruptcy of firms based on information from cash flow statements (Nguyen, Nguyen \& Nguyen, 2019). The cash flow statement and other information may distinguish healthy firms and firms in financial crisis, where information of operating cash flows is the most important indicator of business failure. Firms with a negative operating cash flows is a warning of financial crisis in the following one or two years. In addition to cash flow from operating activities, there are a number of studies on cash flow from investment and financial activities related to predicting the financial situation of firms.

The forecast of bad debts and insolvent debts is very important information for banks that lend capital (Nguyen, 2015; Nguyen \& Thai, 2018; Takasu \& Nakano, 2019; Nguyen \& Lien, 2019). Commercial banks are now very cautious in lending, in compliance with international standards, especially when Vietnam is preparing to apply to the International Financial Reporting Standards (IFRS). 
Ha and Kang (2019) concluded there is also the view that the application to IFRS makes businesses more interested in adjusting profits according to these standards. According to Nguyen and Nguyen (2019), the forecast of future cash flow based on financial statements, especially cash flow statements, is very important information for banks and credit institutions when deciding loans. As for Vietnamese enterprises to expand production, capital flows from lenders play an extremely important role and has been growing steadily in recent years (Hoang \& Vu, 2015).

A number of studies around the world use information on the cash flow statements of users including lenders in the both effective and inefficient information market. Sloan (1996) argued that users of financial statements often give little response to changes in cash flow statements of firms. The market did not respond effectively to the cash flow information of firms. A market is effective when stock prices change according to publicly available information of firms. On the contrary, when the market is ineffective, the information provided by listed companies does not affect users' decisions. Barth, Cram and Nelson (2001) investigated both the effective information market and inefficient information market, showing that financial statement users are not making use of the available cash flow data. The information on the cash flow statement is publicly available, but both lenders and investors are not interested in the information in the statements. Investors and lenders do not seem to be using the information being furnished by the cash flow statement, and continue to rely on the net income figure reported on the income statement instead.

Lenders cannot analyze this useful information without understanding the information provided by the cash flow statement. Information of cash flows from business, investment and financial activities reflects fairly accurately the financial situation of firms (Das, 2019). Signs of bankruptcy of firms are shown first on the cash flow statements. The special cash flow statements for operating activities will help users to recognize the recession period of a business. In addition, when corporate profits go down, the information on the cash flow statement is especially important in determining whether the business can recover or not. A firm that is performing well creates positive net operating cash flow, and uses the excess cash for investing activities and for financing activities.

Therefore, the study focuses on the use of cash flow statement by lenders in case of positive and negative corporate profits. The study examines whether the opposite information in the cash flow statements changes the decision of users of information or not in markets like Vietnam, with a view to further improve the cash flow statements in order to provide better information to users for this important report.

\section{Hypotheses, Data and Research Method}

\subsection{Research hypotheses}

To compare the differences in lenders 'decisions, the authors uses T-tests to examine lenders' differences in whether or not information is available from cash flow statements. Therefore, the thesis contains two comparison tables and each table lists financial statements of two firms, so that we will have two T-tests to examine the hypothesis of short-term lending of organizations:

H1: There is no difference in the decision-making of short-term lenders based only on balance sheet and income statement compared with those based on a full set of balance sheet, income statement and cash flow statement.

There are also hypotheses for long-term lending by institutions.

$\mathrm{H} 2$ : There is no difference in the decision-making of long-term lenders based only on balance sheet and income statement compared with those based on a full set of balance sheet, income statement and cash flow statement.

To do this, the T-tests will make comparisons. Firstly, firms which have positive profit from the balance sheet and income statement without any information on the cash flow statement are compared with firms with a negative cash flow from operating activities. Secondly, firms with negative profit from the balance sheet and income statement without any information on the cash flow statement are compared with firms with positive operating cash flow.

\subsection{Data Collection}

A questionnaire survey was conducted with individuals related to the organization's lenders, the bank credit officers. They were randomly selected from the employees of the banks: Vietnam Commercial Joint Stock Bank for Foreign Trade, Vietnam Bank for Investment and Development and Industrial and Commercial Bank of Vietnam. 150 credit officers received a questionnaire without information on the cash flow statement and 156 credit officers received a questionnaire with full information of the cash flow statement. However, 80 completed questionnaires were returned to the author for each of the two types of question.

According to the survey $62 \%$ of credit officers who answered the questionnaires were men. $55 \%$ of the credit officers' age was in the 26-35 bracket, $29 \%$ were in the $36-45$ bracket, while $16 \%$ were under 26 . The survey also indicates that $71 \%$ of the respondents achieved university degrees, 
$18 \%$ got post-graduate and college degrees, and $11 \%$ had other certification.

\subsection{Research Method}

The questionnaire surveyed two categories of firms. The first, Firm A, has a balance sheet and income statement that emphasize a positive profit which is growing rapidly in the following year; the second, Firm B, only has a balance sheet and income statement indicating a negative profit, while its profit in the previous year was positive. These are two listed companies on the stock exchange. Financial statements of the two firms included real data, which had been audited.

The second assessment of the lenders to businesses, which are the same, Firm A and Firm B in the first assessment, however the two businesses have additional cash flow statements. The firms are selected on the basis of very clear opposition between profit and cash flow from operating activities. Cash flow statements are provided on all three activities of cash flows: cash flow from operation, cash flow from investment, and cash flow from financing; however, the information of operating cash flows is considered the most important. As the profit is the indicator that lenders are interested in, Firm A has growth profit situation in two consecutive years; but the operating cash flows is negative in both survey years, while Firm B has a negative profit in the survey year, its operating cash flows indicates positive.

In the survey to lenders in the second assessment, the author provides information on both cash flow statements, but focuses mainly on the contrast between profit and operating cash flow. According to the author, this is the main information on which to assess the cash flow of the business, and it is closely related to supplementary information for the performance of the business.

Regarding whether or not the lender's decision to make loans is based on the information in the cash flow statement, the author raises two questions. For the first question the author wants to learn about short-term lending decisions, while for the second question, the author wants to find out long-term lending decisions. Long-term lending decisions by both individuals and organizations are risky and have many differences with short-term lending decisions.

Question 1. If you are the lender, should you lend the firm for 1-2 years? (Rated 1: Extremely not recommended to 5: Highly recommended)

Question 2. If you are the lender, should you lend the firm for 5-7 years? (Rated 1: Extremely not recommended to 5: Highly recommended)
These questions are rated on a 5-point Likert scale from 1 to 5 . After answering the questions regarding the lenders' decision in the case of Firm A and Firm B, with or without information from the cash flow of operating activities, the author asks the lenders five questions regarding the lender's familiarity and comfort with regards to their decision. If the lenders do not find any difficulty or problem in assessing the lending ability to the firm, cash flow statements are not really necessary for users; they do not find any problem if the analysis lacks information on the cash flow statements.

Researching the confidence in conducting assessments is a very common research for studies such as Paese and Sniezek (1991); and Wickam (2007). These studies show that people's attitudes influence their decisions and their consideration of whether the information is needed. If information users feel completely comfortable with their decision despite the lack of information on financial statements, the information on the financial statements is, thus, unnecessary. The lender's decision is based on the familiarity with the knowledge and skills in analysis, and the comfort and confidence in recognizing the information given. The author also questioned whether the credibility and comfort of the lender has changed when there is not enough information and when there is sufficient information on cash flow statements. Questions on the lenders' attitude were given:

Question 3. Please indicate your level of agreement on the following issues as 1: Totally opposed to - 5: Strongly agree.

1 . This loan is difficult for your assessment?

2. With the above information, you have sufficient knowledge and skills to perform the analysis of this debt?

3. Assessing your solvency of this firm takes you more time than other firms?

4. You are capable of performing common analytical techniques to assess the solvency of this firm?

5. Are you comfortable in assessing the financial situation of this firm?

The behavioral research questions aim at finding out the lenders' attitude towards the lack of information from the cash flow statements. If they do not change their decision in assessing loans in the presence or absence of cash flow statements, whether lenders are sure of their decisions.

\section{Results and Discussion}

The author tested the equality of the two mean values based on the information of two independent samples (Independent Samples T-tests) for two groups of independent bank credit officers with cash flow statements and without cash flow statements. The Likert scale is numbered from 1 
to 5 where 1 is the lowest level in the assessment, as close to level 5 as the higher of the evaluation. Firstly, comparing the survey organization's short-term lending decision, where the authors surveyed credit officers for positive profit-making businesses, with no information on cash flow statements and a positive profit, while the cash flow statements reflects a negative cash flow from operating activities. We achieve a testing table on the equality of the means of the two groups based on the information of two independent samples from assessing whether credit officers approve loan to businesses in the short term, show in Table 1.

In the first test on the organizations' short-term loan consent, the author surveyed 80 bank credit officers. When there is no information on the cash flow statement, the mean value of the credit officers' opinions about the short-term loan decision is 3.89; however, when the cash flow statement of the firm is available the mean value drops to 3.64. In this case a significant level of observation in the Levene test on the equality of the two variants (Levene's test) is $0.00<0.05$, so equal variances are not assumed. In these tests whether the tests are significant or not is based on the significance level of the observation ( $\mathrm{sig}$ ) in the T-tests for Equality of Means. The result of the test is significant in the observation (sig) = $0.006<0.05$ so the information from the cash flow statement will affect the short-term loan decision of the credit officers. Credit officers will change their short-term lending decision when there is more information on operating cash flows in the cash flow statement.
Second, comparing the organizations' short-term lending decision where the author surveyed credit officers on firms with negative profits, there is no information on cash flow statements and those with negative profit, but positive operating cash flows reflected in the cash flow statements. We achieve two testing tables of equality of mean values for two groups from the information of the two independent samples on evaluating whether lending the business in the short term or not, show in Table 2.

In the test on short-term loan consent in case of negative profit, when there is no information on the cash flow statement, the average opinion of the credit officers about the lending decision is 2.59. However, when there is information on the cash flow statement of the firm, especially the opposite information on operating cash flows compared to the firm's profits, the mean value increases to 2.83 . Thus, it can be seen that when corporate profits are positive, the ability of lenders to lend money to businesses is higher than when the corporate profits are negative. The mean value for short-term loan decisions of credit officers when there is positive profit, with and without information on cash flow statements, are 3.89 and 3.64 respectively.

The test result is significant in the observation of the negative profit, with and without information on the cash flow statement $(\mathrm{sig})=0.009<0.05$ so the information from the cash flow statement will affect the short-term loan decision of the credit officers. Credit officers will change their shortterm lending decision when there is more information on operating cash flows in cash flow statement.

Table 1: Decision on short-term loan of the organizations in case of positive profit

\begin{tabular}{|c|c|c|c|c|c|}
\hline \multicolumn{6}{|c|}{ Group Statistics } \\
\hline & Statements of cash flows & $\mathbf{N}$ & Mean & Std. Deviation & Std. Error Mean \\
\hline \multirow{2}{*}{ Short-term loan } & No information & 80 & 3.89 & .503 & .056 \\
\hline & Full information & 80 & 3.64 & .621 & .069 \\
\hline \multicolumn{6}{|l|}{ Independent Samples Test } \\
\hline & & & & \multicolumn{2}{|c|}{ Short-term loan } \\
\hline & & & & $\begin{array}{l}\text { Equal variances } \\
\text { assumed }\end{array}$ & $\begin{array}{c}\text { Equal variances } \\
\text { not assumed }\end{array}$ \\
\hline \multirow{2}{*}{$\begin{array}{l}\text { Levene's Test for Equality of } \\
\text { Variances }\end{array}$} & \multicolumn{3}{|l|}{$\mathrm{F}$} & 19.134 & \\
\hline & \multicolumn{3}{|l|}{ Sig. } & .000 & \\
\hline \multirow{7}{*}{ t-test for Equality of Means } & \multicolumn{3}{|l|}{$\mathrm{T}$} & 2.797 & 2.797 \\
\hline & \multicolumn{2}{|l|}{ Df } & & 158 & 151.446 \\
\hline & \multicolumn{2}{|l|}{ Sig. (2-tailed) } & & .006 & .006 \\
\hline & \multicolumn{2}{|l|}{ Mean Difference } & & .250 & .250 \\
\hline & \multicolumn{2}{|l|}{ Std. Error Difference } & & .089 & .089 \\
\hline & \multirow{2}{*}{\multicolumn{2}{|c|}{$\begin{array}{l}95 \% \text { Confidence Interval of the } \\
\text { Difference }\end{array}$}} & Lower & .073 & .073 \\
\hline & & & Upper & .427 & .427 \\
\hline
\end{tabular}


Table 2: Decision on short-term loan of the organizations in case of negative profit

\begin{tabular}{|c|c|c|c|c|c|}
\hline \multicolumn{6}{|c|}{ Group Statistics } \\
\hline & Statements of cash flows & $\mathbf{N}$ & Mean & Std. Deviation & Std. Error Mean \\
\hline \multirow{2}{*}{ Short-term loan } & No information & 80 & 2.59 & .610 & .068 \\
\hline & Full information & 80 & 2.83 & .522 & .058 \\
\hline \multicolumn{6}{|l|}{ Independent Samples Test } \\
\hline & & & & \multicolumn{2}{|c|}{ Short-term loan } \\
\hline & & & & $\begin{array}{l}\text { Equal variances } \\
\text { assumed }\end{array}$ & $\begin{array}{l}\text { Equal variances } \\
\text { not assumed }\end{array}$ \\
\hline \multirow{2}{*}{$\begin{array}{l}\text { Levene's Test for Equality of } \\
\text { Variances }\end{array}$} & \multicolumn{3}{|l|}{$\mathrm{F}$} & 12.721 & \\
\hline & \multicolumn{3}{|l|}{ Sig. } & .000 & \\
\hline \multirow{7}{*}{ t-test for Equality of Means } & \multicolumn{3}{|l|}{$\mathrm{T}$} & -2.645 & -2.645 \\
\hline & \multicolumn{2}{|l|}{ Df } & & 158 & 154.346 \\
\hline & \multicolumn{2}{|l|}{ Sig. (2-tailed) } & & .009 & .009 \\
\hline & \multicolumn{2}{|l|}{ Mean Difference } & & -.238 & -.238 \\
\hline & \multicolumn{2}{|l|}{ Std. Error Difference } & & .090 & .090 \\
\hline & \multirow{2}{*}{\multicolumn{2}{|c|}{$\begin{array}{l}\text { 95\% Confidence Interval of the } \\
\text { Difference }\end{array}$}} & Lower & -.415 & -.415 \\
\hline & & & Upper & -.060 & -.060 \\
\hline
\end{tabular}

It is followed by a study of long-term loan consent of bank credit officers. For businesses with positive profits, but negative cash flow from operating activities, when there is no information on cash flow statements, the average opinion of credit officers about long-term lending decisions is 2.69; however, when there is information on the cash flow statement of the firm, especially the opposing information on operating cash flows compared to the profit of firm, the mean value drops to 2.46 .

The result of the test is significant in the observation (sig) $=0.004<0.05$ so the information of the cash flow statement will affect the long-term loan decision of the credit officers. Credit officers will change their long-term lending decision when there is more information on operating cash flows in the cash flow statement. The results are presented in Table 3.

In the test on the organizations' long-term lending consent, when there is no information on the cash flow statement, the average opinion of the credit officers about the loan decision is 1.64. When there is information of the cash flow statement of the firm, especially the opposing information about operating cash flows compared to the profit of the firm, the mean value increases to 1.83 . The mean value in this case is so low because long-term lending is always more risky than short-term lending. In addition, studies have suggested that lenders often underestimate the ability to repay debts of businesses with negative profits and lack of business stability.
The test result is significant in the observation of the negative profit, with and without information on the cash flow statement $(\mathrm{sig})=0.009<0.05$ so the information from the cash flow statement will affect the loan decision of the credit officers. Credit officers will change their longterm lending decision when there is more information on operating cash flows in the cash flow statement.

Based on the tests, we can see that the cash flow statement will affect the decision of the lenders. Credit officers value the information on the cash flow statement in addition to the information from other financial statements

Based on the survey on confidence in making decisions, it can be seen that providing information on cash flow statements affects the comfort and confidence in decisionmaking of bank credit officers. For the first question, the loan is difficult for your assessment in the case of positive profits, without information on cash flow statement; the mean value in the assessment is 2.5. In the case of positive profits, cash flow statements reflecting negative cash flow from operating activities, credit officers find the loan harder to assess, the mean value with an average increase of 2.8. However, in the case of a negative profit, the absence of information on cash flow statements, especially in the case of positive cash flow information, makes it difficult for credit officers to review the loan, then the mean values are rated 3.3 and 3.6, respectively. This is seen when negative profit makes lenders find it more difficult to assess the loan to the business 
Table 3: Decision on long-term loan of the organizations in case of positive profit

\begin{tabular}{|c|c|c|c|c|c|}
\hline \multicolumn{6}{|c|}{ Group Statistics } \\
\hline & Statements of cash flows & $\mathbf{N}$ & Mean & Std. Deviation & Std. Error Mean \\
\hline \multirow{2}{*}{ Long term loan } & No information & 80 & 2.69 & .466 & .052 \\
\hline & Full information & 80 & 2.46 & .502 & .056 \\
\hline \multicolumn{6}{|l|}{ Independent Samples Test } \\
\hline & & & & \multicolumn{2}{|c|}{ Long -term loan } \\
\hline & & & & $\begin{array}{l}\text { Equal variances } \\
\text { assumed }\end{array}$ & $\begin{array}{l}\text { Equal variances } \\
\text { not assumed }\end{array}$ \\
\hline \multirow{2}{*}{$\begin{array}{l}\text { Levene's Test for Equality of } \\
\text { Variances }\end{array}$} & \multicolumn{3}{|l|}{$\mathrm{F}$} & 11.387 & \\
\hline & \multicolumn{3}{|l|}{ Sig. } & .001 & \\
\hline \multirow{7}{*}{ t-test for Equality of Means } & \multicolumn{3}{|l|}{$t$} & 2.938 & 2.938 \\
\hline & \multicolumn{2}{|l|}{ df } & & 158 & 157.166 \\
\hline & \multicolumn{2}{|l|}{ Sig. (2-tailed) } & & .004 & .004 \\
\hline & \multicolumn{2}{|l|}{ Mean Difference } & & .225 & .225 \\
\hline & \multicolumn{2}{|l|}{ Std. Error Difference } & & .077 & .077 \\
\hline & \multirow{2}{*}{\multicolumn{2}{|c|}{$\begin{array}{l}95 \% \text { Confidence Interval of the } \\
\text { Difference }\end{array}$}} & Lower & .074 & .074 \\
\hline & & & Upper & .376 & .376 \\
\hline
\end{tabular}

Table 4: Decision on long-term loan of the organizations in case of negative profit

\begin{tabular}{|c|c|c|c|c|c|}
\hline \multicolumn{6}{|c|}{ Group Statistics } \\
\hline & Statements of cash flows & $\mathbf{N}$ & Mean & Std. Deviation & Std. Error Mean \\
\hline \multirow{2}{*}{ Long term loan } & No information & 80 & 1.64 & .484 & .054 \\
\hline & Full information & 80 & 1.83 & .414 & .046 \\
\hline \multicolumn{6}{|l|}{ Independent Samples Test } \\
\hline & & & & \multicolumn{2}{|c|}{ Long -term loan } \\
\hline & & & & $\begin{array}{l}\text { Equal variances } \\
\text { assumed }\end{array}$ & $\begin{array}{l}\text { Equal variances } \\
\text { not assumed }\end{array}$ \\
\hline \multirow{2}{*}{$\begin{array}{l}\text { Levene's Test for Equality of } \\
\text { Variances }\end{array}$} & \multicolumn{3}{|l|}{$\mathrm{F}$} & 20.241 & \\
\hline & \multicolumn{3}{|l|}{ Sig. } & .000 & \\
\hline \multirow{7}{*}{ t-test for Equality of Means } & \multicolumn{3}{|l|}{$t$} & -2.633 & -2.633 \\
\hline & \multicolumn{2}{|l|}{ df } & & 158 & 154.334 \\
\hline & \multicolumn{2}{|l|}{ Sig. (2-tailed) } & & .009 & .009 \\
\hline & \multicolumn{2}{|l|}{ Mean Difference } & & -.188 & -.188 \\
\hline & \multicolumn{2}{|l|}{ Std. Error Difference } & & .071 & .071 \\
\hline & \multirow{2}{*}{\multicolumn{2}{|c|}{$\begin{array}{l}\text { 95\% Confidence Interval of the } \\
\text { Difference }\end{array}$}} & Lower & -.328 & -.328 \\
\hline & & & Upper & -.047 & -.047 \\
\hline
\end{tabular}

Based on the survey on confidence in making decisions, it can be seen that providing information on cash flow statements affects the comfort and confidence in decision making of bank credit officers. For the first question, the loan is difficult for your assessment in the case of positive profits, without information on cash flow statement; the mean value in the assessment is 2.5. In the case of positive profits, cash flow statements reflecting negative cash flow from operating activities, credit officers find the loan harder to assess, the mean value with an average increase of 2.8 . However, in 
the case of a negative profit, the absence of information on cash flow statements, especially in the case of positive cash flow information, makes it difficult for credit officers to review the loan, then the mean values are rated 3.3 and 3.6, respectively. This is seen when negative profit makes lenders find it more difficult to assess the loan to the business.

For questions related to whether users of information have sufficient knowledge and skills to perform the debt analysis, the lack of information of cash flow statements makes credit officers feel that they do not have sufficient knowledge and skills to assess the situation of the firm. When there is no information of the cash flow statement, the mean value for positive profit is 2.8 ; the mean value for negative profit is 2.9. As for the case of information of cash flow statement is available, the mean value for positive profit is 3.6 and negative profit is 3.4. The survey results are similar to question 4 about performing common analysis to assess the firm's debt.

For the last question about the confidence in assessing the financial situation of the firm, the lack of information of cash flow statements, despite the results are good or bad, affects the confidence of credit officers. In case of positive profit, without information of cash flow statement, the mean value is 2.4 and for positive profit with information of cash flow statement, it is 3.3. Similarly, in the case of a negative profit, without information of cash flow statement, the mean value is 2.2 , and for the negative profit with information of cash flow statements the difference is 3.1.

In summary, for credit officers, the absence of information on the cash flow statement will affect the confidence in the decision - making process of users. For decision makers, the information is necessary as they find it critical.

\section{Recommendations and Conclusion}

\subsection{Recommendations}

Based on the study on lenders influenced by the information provided in the cash flow statement in a market where the information is not effective like Vietnam, listed companies in the stock market should pay more attention to providing information on financial statements, especially cash flow statements. The stock market is a place where listed companies raise funds, and the transparent, complete and voluntary disclosure is the best way to attract lenders' interest. The lenders in the global trend will be more and more interested in cash flow statements. Providing sufficient information on the cash flow statements as well as additional information on the notes to the financial statements will create long-term confidence in the lenders.

Firms should pay attention to raising the qualification of managers as well as the accounting team. Firms should coordinate more closely with reputable training facilities for training courses to improve professional knowledge. The cash flow statement is also an extremely useful report for managers to recognize their business cash flow. Businesses should also modernize their accounting software. Making financial statements is a complex task that requires a lot of effort while the information is now required faster and more accurate by users. To meet this requirement, modern accounting softwares will help businesses. The development of information technology will reduce labor effort and respond more promptly to information provision.

\subsection{Conclusion}

Based on the research results, we can see that the information from the cash flow statements will affect the decision of the lenders, the credit officers, in both short term and long term. In a market where the information is not effective like Vietnam, credit officers value the information on the cash flow statements in addition to information from other financial statements. In addition, the lack of information on the cash flow statements makes the information users lack confidence in making decisions as well as knowledge to assess the financial situation of the business. However, lending institutions still pay more attention to the business situation than to the cash flow situation of the firm.

\section{References}

Barth, M.E., Cram, D.P., \& Nelson, K.K. (2001). Accruals and the prediction of future cash flows. The Accounting Review, 76(1), 27-58. https://doi.org/10.2308/accr.2001.76.1.27

Catanach, H.A. (2000). An emprical study of operating cash flow usefulness in predicting savings and loan financial distress. Advances in Accounting, 17, 1-30. https://doi.org/10.1016/ S0882-6110(00)17004-X

Das, S. (2019). Cash flow ratios and financial performance: a comparative study. Accounting, 5(1), 1-20. https://10.5267/j. ac.2018.6.004

Erich, A.H. (2001). Financial Analysis Tools and Techniques: A Guide for Managers (1st ed.). New York, USA: Mc Graw-Hill Education.

Kwok, H. (2002). The effect of cash flow statement format on lenders' decisions. The International Journal of Accounting, 37(3), 347-362.

Ha, M., \& Kang, M. (2019). IFRS reconciliation adjustment and subsequent meet or beat target earnings. Journal of Asian Finance, Economics and Business, 6(1), 33-45. http://doi. org/10.13106/jafeb.2019.vol6.no1.33

Hoang, T.K., \& Vu, T.D.T. (2015). Determinants of net interest margin of commercial banks in Vietnam. Journal of Economics and Development, 17(2). 69-82. DOI: 10.33301/2015.17.02.04

Nguyen, D.D., \& Vu, T.M.T. (2013). Discussion misstatement in cash flow statement. Journal of Economics and Development, 194(2), 46-53. 
Nguyen, H.A., \& Duong, T.C. (2020). Provincial governance quality and earnings management: empirical evidence from Vietnam. Journal of Asian Finance, Economics and Busines, 7(2), 43-52. https://doi.org/10.13106/jafeb.2020.vol7.no2.43

Nguyen, H.A., \& Nguyen, T.H. (2019). The prediction of future operating cash flows using accrual-based and cash based accounting information: Empirical evidence from Vietnam. Management Science Letter, 10, 683-694. http//dx.doi. org/10.5267/j.msl.2019.9.010

Nguyen, H.A., Pham, T.H., \& Nguyen, T.H. (2020). Impact of working capital management on firm's profitability: empirical evidence from Vietnam. Journal of Asian Finance, Economics and Business, 7(3), 115-125. https://doi.org/10.13106/ jafeb.2020.vol7.no3.115

Nguyen, H.H., \& Lien, T.T. (2019). Factors influencing family business decision for borrowing credit from commercial banks: evidence in Tra Vinh province, Viet Nam. Journal of Asian Finance, Economics and Business, 6(2), 119-122. https://doi. org/10.13106/jafeb.2019.vol6.no2.119

Nguyen, M.S., \& Thai, T.T.L (2018), Revenue diversification and total assets in commercial banks: Evidence from Selected ASEAN Countries. Journal of Economics and Development, 20(3), 20-30. https//doi.org/10.33301/JED-P-2018-20-03-02

Nguyen,T.M.H (2015), Non-performing loans: affecting factor for the sustainability of Vietnam commercial banks. Journal of Economics and Development, 17(1), 93-106. https//doi. org/10.33301/2015.17.01.06

Nguyen.V.C., Nguyen.N.T., \& Nguyen.T.N. (2019). A study on the impact of the factors reflect solvency to the bankruptcy risk of real estate companies: Evidence from Vietnam stock exchange.
Management Science Letter, 9, 1773-1782. http://dx.doi. org/10.5267/j.msl.2019.6.013

Largay. J. A., \& Stickney. C. P. (1980). Cash flows, ratio analysis and the W. T. Grant company bankruptcy. Financial Analysts Journal, July/August, 51-54.

Neill, J. D., Schaefer, T. F., Bahnson, P. R., and Bradbury. M. E. (1991). The useful of cash flow data: a review and synthesis. Journal of Accounting Literature. 10(1), 117-150.

Sloan.R.G. (1996). Do stock prices fully reflect information in accruals and cash flows about future earnings?'. The Accounting Review, 71(July), 289-315.

Takasu, Y., \& Nakano, M. (2019). Conservative Loan Loss Allowance and Bank Lending. Journal of Asian Finance, Economics and Busines, 6(3), 9-18. https://doi.org/10.13106/ jafeb.2019.vol6.no3.9

Turpin, R.A., Smith, K.E.L., Fulmer, J.G. (2005). Insights from the statement of cash flows. Commercial Lending Review, 20(1), 39-42.

Paese, P.W., \& Sniezek, J.A. (1991). Influences on appropriateness of confidence in judgment: Practice, effort, information and decision making. Organizational Behavior and Human Decision, 48(1), 100-130. https://doi.org/10.1016/07495978(91)90008-H

Wickam, P.A. (2007). Overconfidence in new start-up success probability judgment. International Journal of Entrepreneurial Behavior \& Research, 12(4), 210-227. https://doi. org/10.1108/13552550610679168

Zordan, J.A. (1998). Cash flow ratios as predictors of business failure. Florida, USA: Doctoral dissertation, School of Business and Entrepreneurship Nova Southeastern University. 